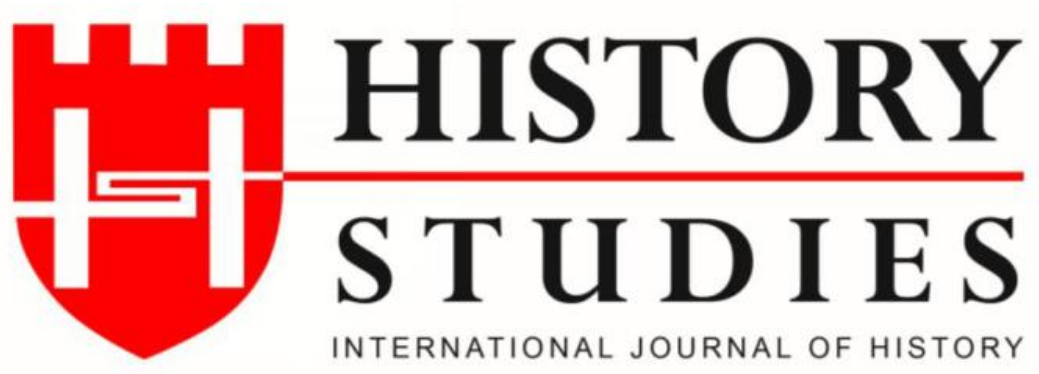

ISSN: 13094173 (Online) 1309 - 4688 (Print)

Volume 12 Issue 4, August 2020

DOI Number: 10.9737/hist.2020.896

Araştırma Makalesi

Makalenin Geliş Tarihi: 31.05.2020 Kabul Tarihi: 21.06.2020

Atıf Künyesi: Ali Duran - Necati Cemaloğlu, “A Historical-Biographical Analysis of A Successful

Educational Leader: İsmail Hakkı Tonguç”, History Studies, 12/4, Ağustos 2020, s. 1703-1731.

\title{
A Historical-Biographical Analysis of A Successful Educational Leader: İsmail Hakkı Tonguç
}

İsmail Hakkı Tonguç: Başarılı Bir Eğitim Liderinin Tarihsel-Biyografi Analizi

\author{
Ali Duran - Prof. Dr. Necati Cemaloğlu \\ ORCID No: 0000-0001-6132-4066 / 0000-0001-7753-2222 \\ Gazi University
}

\begin{abstract}
The purpose of this article was to make a historical-biographical analysis of İsmail Hakkı Tonguç, who was the General Director of Elementary and Early Childhood Education (İlk Tedrisat Umum Müdürü) in the Ministry of Education (Maarif Vekilliği) in Turkey between 1935-1946. Being a qualitative one, this research was designed as a document analysis research, which draws data on the archieve content memories, books, and current literature. İsmail Hakkı Tonguç was a historical successful educational leader who focused his efforts on providing equal educational opportunities and contributing the modernization process of Republic of Turkey. The basic premise of this research was to address the successful educational leadership of him from a historical perspective rather than centering him at the center of the debates on the Village Institutes. Following the content analysis, it was concluded that İsmail Hakkı Tonguç can be considered as both an intellectual educational leader of his age, and a man of the public who cared about his nation's children. Through his educational leadership philosopy, İsmail Hakkı Tonguç added much to Turkish Education System through collaboration of other important figures, such as Hasan Ali Yücel. İsmail Hakkı Tonguç can be considered as paternalist, social justice, transformative, instructional, charismatic, visionary, moral/ethical, democratic, transactional and servant leader.
\end{abstract}

Keywords: Historical-Educational Leadership, Tonguç, The Village Institutes, Success, Moral

Öz: Bu araştırmanın amacı 1935-1946 yılları arasında Maarif Vekilliği İlk Tedrisat Umum Müdürü olan İsmail Hakkı Tonguç’un tarihsel biyografi analizini yaparak, başarılı bir eğitim liderinin tutum ve davranışlarına yönelik tarihsel çerçeveden günümüz ve gelecek için bazı çıkarımlar elde etmektir. Nitel araştırma modellerinden döküman analiz yöntemi ile desenlenen bu araştrmanın verileri Türkiye Cumhuriyeti Cumhurbaşkanlığı Devlet Arşivleri Başkanlığı Cumhuriyet Arşivi, Tonguç’un kendi kitapları, literatürdeki araştırma ve hakkında yazılan diğer kitaplara dayalıdır. İsmail Hakkı Tonguç Türkiye Cumhuriyeti'nin mdoernleşme sürecine ve özellikle köylerdeki öğrencilerin eşit eğitim firsatlarına erişebilmesi için çaba harcamış tarihi başarılı bir eğitim lideridir. Bu araştırmada İsmail Hakkı Tonguç Köy Enstitüleri bağlamında incelenmekten ziyade, yakın 
tarihimizde yer almış başarılı bir eğitim lideri yönü ile değerlendirilmiştir. İçerik analizi sonucu elde edilen bulgularda, Tonguç'un kendi döneminde başarılı bir entelektüel olduğu ve vatan evlatları için paternalist, dönüşümcü, sosyal adalet, karizmatik başta olmak üzere pek çok liderlik davranışı sergilediği sonucu elde edilmiştir. Tonguç, Hasan Âli Yücel başta olmak üzere birçok önemli meslektaşı ile birlikte Türk Eğitim Sistemi’ne katkı yapmıştır. Elde edilen bulgular 1şığında, İsmail Hakkı Tonguç, paternalist, sosyal adalet, dönüşümcü, öğretimsel, karizmatik, vizyoner, ahlaki/etik, demokratik, işlemci ve hizmetkâr lider olarak değerlendirilebilir.

Anahtar Kelimeler: Tarihi-Eğitimsel Liderlik, Tonguç, Köy Enstitüleri, Başarı, Ahlak

\section{"John Dewey in America, Kerschensteiner in Europe, and İsmail Hakkı Tonguç in Asia"}

M. Rauf INAN

\section{Introduction}

Throughout the world history, educational leaders have played a key role in the hard times of the countries, navigating either nations or educational organizations. Further, successful educational leadership always matters in the histories of countries.

The notion "with great power comes great responsibility" points to the opportunity and the risks involved in great change times in social justice systems. However, there is a "black hole" in the literature in terms of training future educational leaders and educational leaders' orientation towards development of social justice. ${ }^{1}$ Educational leadership is a position that involves such imperatives as managerial, social, instructional, political, and moral. ${ }^{2}$ Similarly, successful educational leaders are on great demand today, so successful educational leadership appears to be on the minds people everywhere. ${ }^{3}$

Everything in the world is no exception of change with the course of time. The change in the process of history occurs on a constant basis, so human being cannot freeze the reality but unearth it by looking at historical evidence. ${ }^{4}$ The historical research approach is often in alliance with biographical one and together they form the historical-biographical approach. ${ }^{5}$ Through historical studies, we often make comparisons between past and present, hoping that knowledge of the past will assist us to make inferences about the present, even maybe on the future. We are surrounded by traces of the past, and historical experiences can help us to enrich our understanding of the society in which we live. It is the power of history which can provide us with the means to understand the past, to distinguish myth from reality, and to see the elements that can shed light on the future. Therefore, the study of history holds practical and

\footnotetext{
${ }^{1}$ Izhak Berkovich, "Reflections on Leadership Preparation Programs and Social Justice," Journal of Educational Administration 55, no. 3 (February 2017): pp. 261-279, https://doi.org/10.1108/jea-02-20160018.

2 William D. Greenfield, "Toward a Theory of School Administration: The Centrality of Leadership." Educational Administration Quarterly, 31, no. 1 (1995), pp. 61-85. doi:10.1177/0013161x95031001005.

${ }^{3}$ Robert H. Palestini, A Commonsense Approach to Educational Leadership: Lessons from the Founders. Lanham: R\&L Education, 2012, p.5.

${ }^{4}$ Bill McDowell, Historical Research: A Guide for Writers of Dissertations, Theses, Articles and Books. London: Routledge, 2013, p.3.

${ }^{5}$ Wilfred Guerin, Earle Labor, Lee Morgan, Jeanne C. Reesman \& John and John R. Willingman, A Handbook of Critical Approaches to Literature. New York: Oxford University Press, USA, 1992.
} 
educational value. ${ }^{6}$ In this sense, this nature of history can be suggested to navigate us for the future, by providing evidence from the past.

Historically, the remedies for education were often attempted to be found in business sector. In spite of the partial benefits of this endeavour, it is better to follow the traces of successful educational leaders in its own history. ${ }^{7}$ In this light, a plethora of historical research studies have been conducted on past educators credited with their ideas, opinions, philosophies, and exemplary leadership behaviours that changed the course of history. ${ }^{8}$

Upon delving deeply into the educational history in Turkish context, one can see that there were successful figures to whom the literature points in the educational history of Turkey. In this sense, Ziya Gökalp, Hilmi Ziya Ülken, Mümtaz Turhan, Nurettin Topçu, Cemil Meriç, Erol Güngör and Hasan Ali Yücel are some examples from the literature. It is certainly an undeniable fact that the list of successful historical figures who focused on education, social issues, and culture cannot be confined to the names mentioned above in the glorious and renowned Turkish History and Turkish Education System. Similarly, one of the most important successful educational leaders over the course of Turkish History is İsmail Hakkı Tonguç, the General Director of Elementary and Early Childhood Education (İlk Tedrisat Umum Müdürü) in the Ministry of Education (Maarif Vekilligi) in Turkey between 1935-1940 temporarily and 1940-1946 officially. Previous research on İsmail Hakk1 Tonguç (henceforth, Tonguç) has revealed that there have been some research on his biography, ${ }^{9}$ his thoughts on education ${ }^{10}$, and his main teachings, ${ }^{11}$ his thoughts on Turkish Education, ${ }^{12}$ the Village Institutes, ${ }^{13}$ a story of him, ${ }^{14}$ and his effect on the Socio-Cultural Change of Republican Period. ${ }^{15}$ On the other hand, it is seen that the scientific focus on Tonguç is mostly displayed in the recent studies on the Village Institutes, established as a "Village Teacher Training Schools" in 1937, later named as "the Village Institutes", designed based on the scientific domains in line with the needs and conditions of the country, and which were phased out in the mids of 1950s. In this sense, he was addressed in such studies as memories in the Village Institutes,${ }^{16}$ educational philosophy in the Village Institutes and educational curricula applied in village institutes, ${ }^{17}$ closing the

${ }^{6}$ Palestini, ibid., p.1-2.

${ }^{7}$ Ibid., p.5.

${ }^{8}$ Daniel W. Stuckart, and Jeffrey Glanz, Revisiting Dewey: Best Practices for Educating the Whole Child Today. Lanham: R\&L Education, 2010.

9 Engin Tonguç, Bir Ĕgitim Devrimcisi İsmail Hakkı Tonguç Yaşamı, Öğretisi, Eylemi. İzmir: Yeni Kuşak Köy Enstitülüler Derneği Yayınları, 2009.

10 Abdullah İnaltekin, “İsmail Hakkı Tonguç ve İsmail Hakkı Baltacıŏlu’nun eğitim görüşleri ve uygulamaları üzerine bir çalışma.” Master's thesis, Yeditepe Üniversitesi, 2002. Yöktez (117579).

${ }_{11}$ Mustafa Kandil, "İsmail Hakkl Tonguç ve Mümtaz Turhan’ın Eğitim Görüşleri Üzerine Bir Değerlendirme”. Master's thesis, Yeditepe Üniversitesi, 1986. Yöktez (357907).

12 Osman Yalçın, Bir Eğitimcinin Anıları: İş Eğitimi Yolunda 46 Yll. İstanbul, YA-BA Yayınları, 1983.

${ }^{13}$ Pakize Türkoğlu, Tonguç ve Enstitüleri. İstanbul: Yapı Kredi Yayınları, 1997

${ }_{15}^{14}$ Mehmet Cimi, Tonguç Baba: Ülkeyi Kucaklayan Adam. İstanbul: Kanes Yayınları, 2015.

${ }^{15}$ Hacer Çelik, Hacer. "Cumhuriyet Dönemi Sosyo-Kültürel Değişim Üzerinde Türk Aydınının Etkisi (İsmail Hakk1 Tonguç Örneği).” U. Ü. Fen-Edebiyat Fakültesi Sosyal Bilimler Dergisi, no.18 (2010), 111-124.

${ }_{17}^{16}$ Mahmut Makal, Köy Enstitüleri ve Ötesi: Anılar, Belgeler. İstanbul: Literatür Yayıncılık, 1979.

17 Bahadırhan Ceylan, "Köy Enstitülerinde Uygulanan Eğitim Programlarının Çoklu Zekâ Kuramı Açısından İncelenmesi”. Master's thesis, Sivas Cumhuriyet Üniversitesi, 2020. Yöktez (617223). 
Village Institutes ${ }^{18}$ the Village Institutes in the Turkish literature, ${ }^{19}$ artistic activities ${ }^{20}$ and rural development policies. ${ }^{21}$ Further, one of the preliminary work was conducted to examine the Village Institutes in the doctoral dissertation named as "The Village Institute movement of Turkey: An educational mobilization for social change", by visiting the schools in person. ${ }^{22}$

An examination of literature shows that most of the studies and books on Tonguç have been naturally written in Turkish. However, it is worthy noting that Tonguç was one of the leading educational leaders who had left deep traces in the Turkish Education System, so his historicalbiographical analysis, thoughts and teachings will always matter for those related to education at national and international level. To achieve this, there needs to be new studies in English language. An examination of international literature, there have been a few studies citing the Village Institutes ${ }^{23}$ and Tonguç, ${ }^{24}$ but no study focusing solely on his successful educational leadership has been found from a historical perspective.

A village institute graduate who was a student of Tonguç mentions in the book Tonguç and His Institutes (Tonguç ve Enstitüleri) that such international figures as Pestalozzi or John Dewey are studies in the coursebooks of students in the Faculty of Educations, but students don't focus on historical educational reformers such as İsmail Hakkı Tonguç or the Village Institutes in their courses. ${ }^{25}$ This shows that Tonguç hasn't been given the real appreciation in practice so far despite abundant research on the Village Institutes. Another point needed to be mentioned is that most studies on him have accumulated in the context of the Village Institutes. There is certainly no problematic issue with this, but Tonguç was an important historical figure, and his passionate would have emerged in anyway with different names or designs if there hadn't been the Village Institutes. Therefore, it can be argued that there is a gap in the literature which needs to be addressed in terms of highlighting his successful educational leadership from historical perspectives.

The historical analysis of educational leadership styles, attitudes and behaviours of Tonguç, therefore, can be claimed to be a neglected issue in the literature. The compelling evidence on his educational background mostly rely on the memories, narratives, and chronological events. Further, another point in the literature on Tonguç is that his successful educational leadership is often evaluated in the context of Village Institutes, an educational initiative to provide equal educational opportunities for those living in the villages to help students to be able to adapt into the urban life. There is also a growing body of research on the Village Institutes, which refers to Tonguç. Some of the previous research has also focused the ideological foundations of these

18 Fevzi Özgür Altın, “Köy Enstitülerinin Kapatılmasında Yazılı Basının Rolü: Gündem Berlileme Kuramı Kapsamında Ulus ve Vatan Gazetelerinin Incelenmesi." Master's thesis, Atılım Üniversitesi, 2020. Yöktez (616420).

19 Erkal Köroğlu, “Türk Romanında Köy Enstitüleri Olgusu Üzerine Bir Inceleme." Master's thesis, Kastamonu Üniversitesi, 2019. Yöktez (593077).

${ }^{20}$ Derya Tosun, “Köy Enstitülerinde Sanatsal Faaliyetler”. Master's thesis, Dokuz Eylül Ünivertiesi, 2019. Yöktez (601876).

21 Ezgi Kaplan, "Cumhuriyet Dönemi’nde Kırsal Kalkınma Politikaları Örnek Bir Model: Köy Enstitüleri." Master's thesis, Mimar Sinan Güzel Sanatlar Üniversitesi, 2017. Yöktez (484237).

${ }^{22}$ Fay Kirby-Berkes, "The Village Institute movement of Turkey: An educational mobilization for social change." PhD diss., Columbia University, 1960. ProQuest (0225862).

23 Ahmet F. Korur, "Democratic Education, The Village Institutes System in Turkey And its Art Education Component." PhD diss., The Ohio State University, 2002. ProQuest (3049056).

24 Özlem Zabitgil, "The Poetry of Turkish Village Institute-Educated Poets: Social Commentary on a Developing Nation." PhD diss., The Pennsylvania State University, 2010. ProQuest (3436113).

${ }^{25}$ Türkoğlu, ibid., p.9. 
schools. There were lots of individuals and groups who supported the establishments of these schools ${ }^{26}$ and came out against them. ${ }^{27}$

Quite aside from all discussions in the literature on Tonguç and the Village Institutes, this inquiry is just to address the successful educational leadership styles, attitudes and behaviours of Tonguç from a historical-biographical analysis, particularly between 1935-1946, during which he was the General Director of Elementary and Early Childhood Education. The nature of this paper is not to separate Tonguç from the context of the Village Institutes or not to repeat the similar literature, but to highlight the successful historical and educational leadership that mattered in its own conditions so that we can make some conclusions for today and future. When we consider all these, it can be noted that focusing on the historical-biographical analysis of Tonguç will be worthy to provide new insights into the literature.

\subsection{Purpose of the Study}

The core purpose of this research was to focus on the historical-biographical analysis of Tonguç in order to reveal the main cornerstones in the life of a successful educational leader, and to draw some conclusions from the past to the future. The main concern of this paper is looking back and looking forward via a historical perspective. By delving into Tonguç's historical-biographical analysis, we put our efforts to define the successful educational leadership behaviours manifested by him and to present a frame for today and future. Based on the main research problem of this effort, the following questions framed the scope of this inquiry:

1. What was the main education philosophy of Tonguç in a historical perspective?

2. What were his successful educational leadership styles, attitudes and behaviours that affected the development of educational history of Turkish Education System?

3. What conclusions can be drawn from the historical evidence on a historical successful educational leader?

\section{Method}

\subsection{Research Model}

Qualitative research model was adopted while conducting this research as it allows researchers to study a phenomenon in its natural settings, by revealing the meanings people bring to them. ${ }^{28}$ Qualitative data relies on the kinds of data or information that are collected. Moreover, the data obtained through qualitative methods provides depth and detail. ${ }^{29}$

\subsection{Research Design}

This qualitative research was conducted employing historical methodology which seeks to examine the past human experiences bound by context to elucidate its possible impact on the present. ${ }^{30}$ Within this scope, the document analysis research design was employed since it deals

\footnotetext{
${ }^{26}$ Türkoğlu, ibid.

${ }^{27}$ Yücel Hacaloğlu, Neden Köy Enstitüleri Değil?. İstanbul: Toprak Yayınları, 1962.

${ }^{28}$ Norman K. Denzin, and S. Lincoln Yvonna, The SAGE Handbook of Qualitative Research. Thousand Oaks: SAGE Publications, 2017.

${ }^{29}$ Micheal Quinn Patton, Qualitative Research \& Evaluation Methods: Integrating Theory and Practice. Thousand Oaks: SAGE Publications, 2015.

30 John W. Creswell, Qualitative Inquiry and Research Design: Choosing Among Five Approaches. Thousand Oaks: SAGE, 2013.
} 
with existing historical records in the history as well as scientific data. Document analysis research is a popular research technique, particularly for the archival documents. ${ }^{31}$

\subsection{Data Collection}

The main sources consulted when doing this research were documents written by Tonguç himself, including some of his letters. ${ }^{32}$ Private letters and diaries appear to offer fruitful sources of information. ${ }^{33}$ Further, the data in this research draws on (a) the archieve content in the Directorate General of State Archives, (b) previous research on Tonguç, and (c) literature on the Village Institutes. Past documents generally are the form of primary evidence, so they can make invaluable contributions to a qualitative study. ${ }^{34}$

\subsection{Data Analysis}

In order for the analysis of the documents and literature, the content analysis method was employed in this research. Content analysis is used in examining archieved materials to record the related information. ${ }^{35}$ Three steps are suggested to content analysis: skimming (superficial examination), reading (thorough examination), and interpretation. ${ }^{36}$

Due to the richness in the archieve contents, researchers critically need to evaluate the documents. The documents shouldn't be considered as the exact recordings of the events or the phenomena. ${ }^{37}$ In this sense, the credibility was addressed through a detailed archieve screening and a thorough literature examination. The transferability is provided with the histocial archieves as one can reach them any time. For the dependability, we discussed our findings with the literature. When it comes to the confirmability, we relied on the historical facts while interpreting the data.

\section{Findings}

The findings in this study are presented in two subsections. First, the main events in his life are included without focusing the details. Second, his successful educational leadership are discussed in terms of historical context and leadership perspectives.

\section{1. İsmail Hakkı Tonguç's Biography (1893-1960)}

Based on the analysis of the archieve content, the books, and the literature, the findings are chronologically structured as follow. Figure 1 displays the sequence followed.

\footnotetext{
31 Glenn A. Bowen, "Document Analysis as a Qualitative Research Method." Qualitative Research Journal 9, no. 2 (2009), pp. 27-40. doi:10.3316/qrj0902027.

${ }^{32}$ Engin Tonguç, Mektuplarla Köy Enstitüsü Yılları. Ankara: Güldikeni Yayınları, 1999.

${ }^{33}$ McDowell, ibid., p.54.

${ }^{34}$ Robert K.Yin, Qualitative Research from Start to Finish, 2nd ed. New York: Guilford Publications, 2015.

35 Klaus Krippendorff, Content Analysis: An Introduction to Its Methodology. Thousand Oaks: SAGE Publications, 2018.

${ }^{36}$ Bowen, ibid., p.29.

${ }^{37}$ Ibid., p. 36.
} 


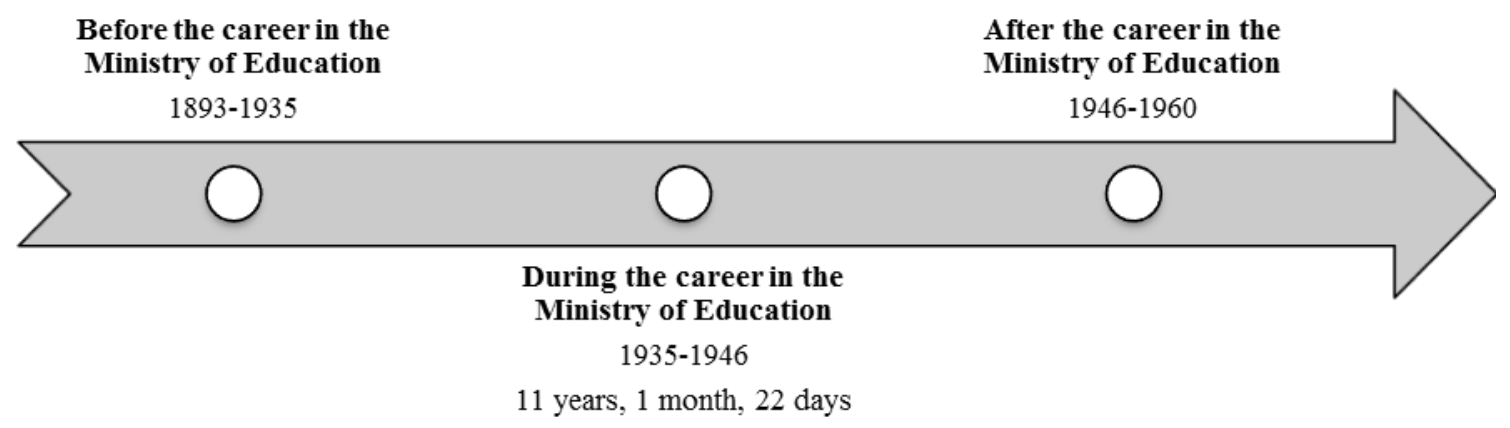

FIGURE 1. The chronological order

\subsubsection{Before the career in the Ministry of Education (1893-1935)}

Tonguç was born in Tatar Atmaca Village (what is today Sokol) in 1893. The village where he was born was affiliated to Silistre (what is today Silistra), a town located in the northeastern Bulgaria, which was once the territory included in the Ottoman Empire. His father's name was İdris, and his mother's name was Vesile. There were eight children in the family, and Tonguç was the oldest one. Süleyman, Osman, İbrahim, Beytullah, Selime, Zekeriya and Yahya were the names of his siblings. Having finished primary school in his village, Tonguç enrolled in Silistre Rushdiyya School (middle school), and graduated from there in 1907. Silistre, located near the Tuna River (what is today the Danube River), was a new settlement for him, where he had the opportunity to experience urban life at the time. During the school years in Silistre, a room was rented for him and one of his classmates. Upon completing his education there, he had to return to his village despite his ambition to go on his education, but there was no school for him to realize his aspirations. Then, his only choice was to arrive in İstanbul. After he had been busy with agriculture in his village for some time, he came to İstanbul in $1914 .^{38}$

There is no exact evidence as to how he arrived in İstanbul, but according to his memories, he was in İstanbul in 1914. Following several attempts to enroll in a teacher training school, he managed to enroll in the Kastamonu Teacher Training School. In the recollections, this process is narrated as follows. ${ }^{39}$

"After waiting and struggling for some time, İsmail was able to enter the room of Minister of Education Şükrü Bey. The minister enrolled him to the Kastamonu Teacher Training School, which was a boarding school when he read Tonguç's letter of application. Tonguç was very pleased and felt as if he had conquered the world."

Upon arrival to Kastamonu, he saw the name of the Teacher Training school (Darülmuallimin), and his own expressions are documented as follows: ${ }^{40}$

"I managed to find the way to the school by asking the direction. I was very surprised when I saw the signboard showing the name of the school. When entering the inside, I was sitting on top of the world."

Remembering the promise of the Minister as to the fact that he could be transferred to İstanbul in the event of any problem in Kastamonu, he sent a letter to the Minister. Having received a positive answer, he wanted to be transferred to the school in İstanbul after almost

38 Tonguç, Bir Ĕ̈itim Devrimcisi, p.11

${ }^{39}$ Ibid., p. 21

${ }^{40}$ Ibid., p. 22 
one and half year as a student in Kastamonu. ${ }^{41}$ This event may have made him to allow students in the Village Institutes to be able to send letters to the educational leaders in higher positions, as well.

Upon arrival in İstanbul in May 1916, he learned the fact that the second name "Hakkl" was added to his identity card. Adding a second name was a common practice during those days in order to prevent the misunderstandings in the names of the students, and it would be often practiced by teachers. He pursued a very successful period in İstanbul. The education phenomenon was important policy for the Ottoman officials during those years despite the conflicts. The graduates of teacher training schools weren't recruited to the army when the World War I started. In this context, he was qualified to be sent to Germany for further education. Those students had been called back when there were conflicts with foreign powers at the time in the Ottoman Period. ${ }^{42}$

İsmail Hakkı Tonguç got education in the Ettlingen Teacher Training School. The education in the Ettlingen Teacher Training School in Karlsruhe, Germany can be considered as a significant turning point in his life as he had the chance to observe the lives of the villagers in Germany. Later, the students who had been sent to Germany returned to İstanbul, which was under the siege of foreign powers. Tonguç was appointed to the Eskişehir Teacher Training School (Darülmuallimin) as an art, craft and physical education teacher, and started to his duty on the $11^{\text {th }}$ of September, 1919 with the staff code $62 .{ }^{43}$ At the time, Mustafa Kemal Atatürk was leading the congresses and organizing the new foundations of Republic of Turkey.

The successful educational leadership can be said to have started during the period he had spent in Eskişehir. In other words, Tonguç was observing the ignorance having spreaded through the region. As a teacher, he was displaying teacher leadership behaviours and visiting the villages around. At the same time, there were attempts to occupy Eskişehir by the foreign powers. The decision of the state that teachers wouldn't be recruited in the army for the building of the future teacher training schools was still followed. Eskişehir was under the intense attacks of the occupiers, so Tonguç left the city and moved to Ankara in 1921. ${ }^{44}$

During those years, Republic of Turkey was being built in the leadership of Ataturk and the new assembly was established on the $23^{\text {rd }}$ April, 1920. The students who had been sent to Germany for education were intended to send Germany back to complete their education as Atatürk knew that the education was one of the most crucial factors in the development of a nation.

Tonguç once more arrived in Karlsruhe on the $3^{\text {rd }}$ of September, 1921. The second term in Germany was different from the first one in that Tonguç was staying in a host family rather than a dormitory. He was reading lots of books from pedagogy, child psychology, agriculture to religions, poets, fishery, etc. However, his main interest focused on the vocational education both theoretically and practically. This shows that he adopted the idea that development was possible through production of goods and services. Tonguç returned to İstanbul from Austria through Bulgaria.

Upon arrival to İstanbul, he was appointed to Konya Teacher Training School (Darülmuallimin) as an art, craft and physical education teacher in 1922. Tonguç was known as

${ }^{41}$ Tonguç, Bir Eğitim Devrimcisi, p.27

42 Ibid., p.33

${ }^{43}$ Ibid., p.39

${ }^{44}$ Ibid., p.52 
a teacher who was serious, hardworking, authoritarian, and disciplinarian. However, students didn't hesitate to talk to him as he was open to his students. He was spending time with his students outside the classroom, as well. ${ }^{45}$

Tonguç was appointed to the Ankara Teacher Training School (Darülmuallimin) in 1924, and worked as a teacher and a vice-president in this school. This assignment can be seen the first official administrative position in his career. Later, he was temporarily appointed to the Adana Teacher Training School (Darülmuallimin) as a teacher almost for a year. The changes in his career can be attributed to the lack of teachers across the country or the conflicts in the administrative positions in the Ministry of Education.

During those days, Jown Dewey, a famous educational reformer and contributed to Turkish Education System, ${ }^{46}$ was invited to Turkey in 1924 . The recommendations by Dewey were mostly taken into consideration in the practice. Further, the model of rural teachers training schools was taken as an example while designing the Village Institutes in Turkish educational history ${ }^{47}$. Tonguç noted that the recommendations by Dewey was an important contribution, but also argued that not embracing all recommendations on education reform by Dewey was a missed opportunity for fifteen years. ${ }^{48}$

Tonguç had taken an order from the Ministry of Education, which informed him about his assignment on the international visits to educational institutions in Germany, France, and England. First, he would attend a celebration in Napoli University, next visit several schools and then attend an in-service training in Leipzig, Germany. During these visit, he had the chance to observe rural schools and to experience the on-the-job training, which refers to a hands-on method of teaching knowledge and skills. He also met with a German professor and educational theorist, Georg Kerschensteiner, a dominant figure in the vocational education in Germany at the time before the training in Leipzig. ${ }^{49}$ Appendix 1 displays the official decree about the assignment of this international visit.

Following the international visits in the first half of 1925, Tonguç was appointed to the Ankara Teacher Training School (Darülmuallimin) in 1924, and worked as a teacher. In 1926, he was appointed to a new position by the Minister as the director of school museum in the scope of the Ministry of Education. This was the first administrative position in the Ministry of Education's organization in Ankara. Appendix 2 displays the official decree about this appointment. $^{50}$

Tonguç started his new position on the $11^{\text {th }}$ of March, 1926. During the first years of his duty, he organized in-service training courses for art and craft teachers and brought instructors from Germany. He was the director of the course and translated the expressions of the German instructors. By the way, one of the attendants of the course took his attention. This participant was the teacher, Nafia Kâmil, who would be his wife on the $26^{\text {th }}$ of January, 1927. In the following year, their first child, Engin was born on the $26^{\text {th }}$ of April, 1928. There was also another important development during 1927-1928. His family migrated to Turkey in the fall of

\footnotetext{
${ }^{45}$ Ibid., p.60

${ }^{46}$ Selahattin Turan, "John Dewey's Report of 1924 and his recommendations on the Turkish educational system revisited." History of Education 29, no. 6 (2000), p. 544. doi:10.1080/00467600050163174.

${ }^{47}$ Sabri Büyükdüvenci, The New Scholarship on Dewey. Edited by James W. Garrison. Berlin: Springer Science \& Business Media, 1995, p.225.

${ }^{48}$ Tonguç, Bir Eğitim Devrimcisi, p.67

${ }^{49}$ Ibid., p.71

${ }^{50}$ Ibid, p. 77
} 
$1927 .{ }^{51}$ They came to Turkey through Romania. The archieve document on this arrival is displayed in Appendix 3.

During the next years, Tonguç continued his service, and also published books and articles. He particularly focused on the on-the-job training. He translated important texts on education, as well. During the last quarter of 1929 , he and a colleague went to some countries in Europe to examine and bring contemporary educational tools and materials. While he was maintaining his studies and doing his duty, he had health problems and underwent an operation in 1931. Having recovered, he focused on writing the course books on art and craft for the teacher tranining schools. During 1930-1933, he delved deeply into the international books to contribute to the Turkish Education System. In 1934, Tonguç was temporarily appointed as the Adminisrator of Gazi Education Institute. Further, at the beginning of the 1934, his son got ill and stayed in hospital. During this period, he got the surname "Tonguç", based on the law, issued on the $21^{\text {st }}$ of June, 1934.

\subsubsection{During the career in the Ministry of Education (1935-1946)}

The story of his career as the director of Elementary and Early Childhood Education began as follows. Following the appointment of Saffet Arıkan, a famous Turkish politican, as a new Ministe, Tonguç was maintaining his career as the administrator of the Gazi Education Institute. Upon recommendations, Tonguç was invited to the Minister of Education and was told that he was the new director of Elementary and Early Childhood Education. He had a different personality with modest profile in the hierarchy and bureaucracy of the Ministry of Education. Having started to work as the General Director of Elementary and Early Childhood Education temporarily on the $3^{\text {rd }}$ of August, 1935, Tonguç was officially appointed to the position on the $31^{\text {st }}$ of January, 1940 and served until the $21^{\text {st }}$ of September, 1946. He had a total of 11 years, 1 month, 22 days service as the General Director of Elementary and Early Childhood Education. Appendix 4 displays the official decree about the appointment.

During the first years of his career, there were 13 teacher training schools in Turkey, and a total of 2805 pre-service teachers were studying in these schools. On the other hand, almost 800 teachers stopped teaching for a variety of reasons. Tonguç thought that they would need more teachers for the development of the villages.

During those years, his second son whose name was Yalım was born on the $23^{\text {rd }}$ of September 1936, but he died of an injecion practiced by a child doctor, who was argued that he practiced the injection without allergy testing, so the child's body showed reaction. This made the whole family very sad. ${ }^{52}$

Following days, Tonguç and his colleagues prepared a report on the new reforms in education to be submitted to the board of ministers in the leadership of the President. He was preparing the new models in education, and was looking for good practices. Within this context, he was sent to an international visit from Bulgaria, Hungary, Czechoslovakia to Germany so that he could make visits and note on good practices of the education system in these countries. Appendix 5 displays the official document, which was signed by the President Mustafa Kemal Atatürk.

Upon arrival to Ankara from the visits lasting for almost two months, there were lots of tasks to be done. He had prepared a detailed report that reflected the rise of Germans in terms of education, particularly vocational education.

${ }^{51}$ Ibid., p.99

52 Tonguç, Bir Eğitim Devrimcisi, p.393 
The year 1938 was an upsetting year in which the founder of Republic of Turkey, Gazi Mustafa Kemal Atatürk died on the $10^{\text {th }}$ of November, 1938. This was a mournful term for Turkish people. The corpse of Atatürk was brought to the Grand National Assembly of Turkey, usually referred to as TBMM. Tonguç and his family visited the catafalque and respected their leader.

The new president of Republic of Turkey was İsmet İnönü. There were some changes in the government system, as well. Hasan Âli Yücel, a philosophy teacher, an administrator, and a member of parliament, was appointed as the new Minister of Education on the $28^{\text {th }}$ of December, 1938. Tonguç asked the new minister to discharge him but Hasan Âli Yücel uttered that he could go on his career as the director of Elementary and Early Childhood Education. ${ }^{53}$

Tonguç informed Hasan Âli Yücel about the current situation of the teacher education at the time, and suggested several reforms. Following a visit for the purpose of supervision in the villages of Ankara, Tonguç wrote about this visit to be published.

Tonguç, on the other hand, was busy with his book that reflects his educational philosophy and implementations formed after many years of visits, observations, reading, experiences and research. The book was called as Canlandirlacak Köy (The Village to be Developed), which focuses on the teacher training, village life, developments of the villages, and the Village Institutes, by Tonguç in 1939 . Tonguç wrote these sentences in the book: ${ }^{.5}$

...Those who attempt to develop villages without planning, uncouncious and mechanic efforts waste their energies... It is not essential to develop villages through external motivations but essential to make them develop inside, namely educating them...

Until 1940, Tonguç was busy with supervisions and other managerial works. By the way, teacher training to the those living in the villages. The graduates of the village institutes would be recruited as teachers in the villages, particularly teachers' own villages.

The main purpose of the Village Institutes were to make rural people literate, to train teachers to be able to work in the rural parts of the country, to provide villagers with the scientific agricultural methods, and to improve the social and cultural aspects of the villages. ${ }^{55}$

Having long-lasting efforts and preparations, the law regarding the Village Institutes was enacted on the $17^{\text {th }}$ of April, 1940. The law was called as "The Village Institutes Law with the reference 3803". Based on the law, four teacher training schools were converted into village institutes and 17 more schools were build between 1940-1948. Figure 2 displays the school mapping of the Village Institutes.

\footnotetext{
${ }^{53}$ Tonguç Engin, Bir Eğitim Devrimcisi, p.248.

${ }^{54}$ İsmail Hakkı Tonguç, Canlandırılacak Köy. İstanbul: Türkiye İş Bankası Kültür Yayınları, 1970, p.22.

55 Türkoğlu, Ibid., p.149.
} 


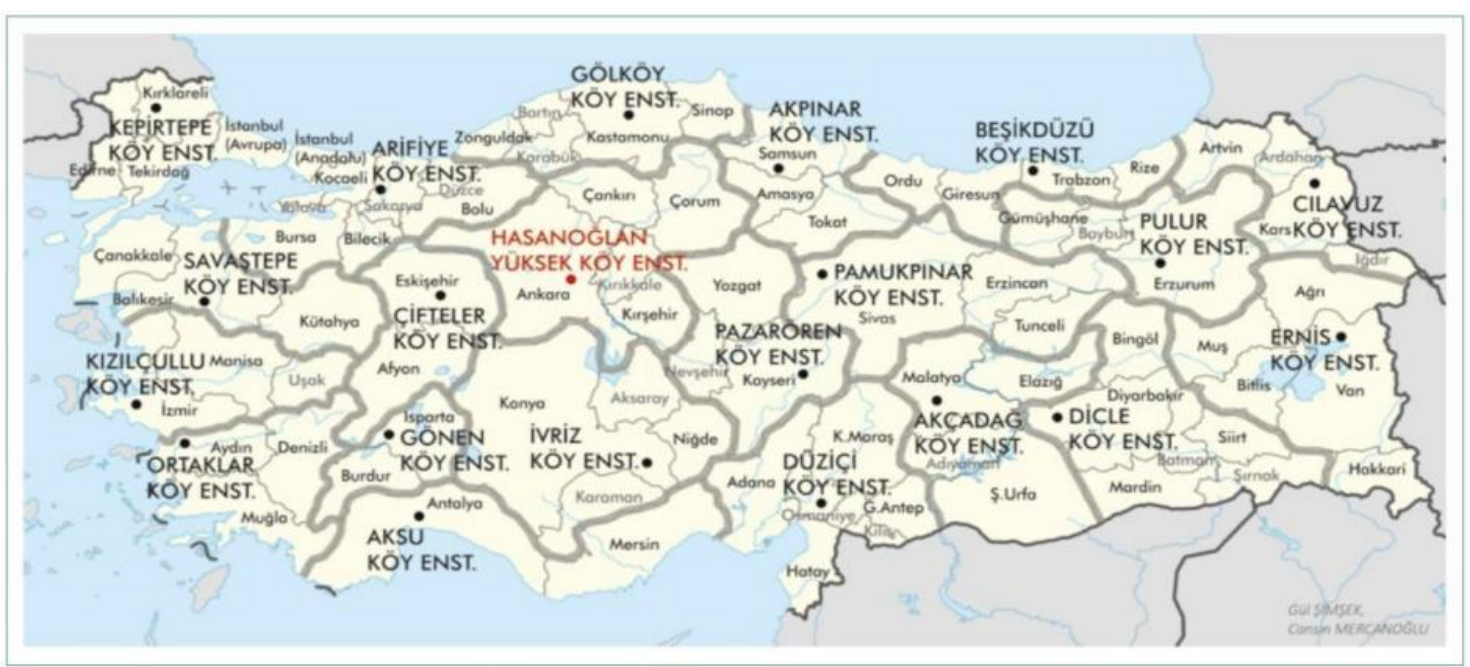

FIGURE 2. The school mapping of the Village Institutes ${ }^{56}$

A total of 20 schools were built during the leadership of Tonguç except the last one built in 1948 , when he was in a different position in the Ministry of Education. ${ }^{57}$ Further, as shown in Figure 2, 18 of the Village Institutes were located in the villages. ${ }^{58}$

The Village Institutes were significant institutions which contributed to the Turkish Education System, particularly rural education as well as development. ${ }^{59}$ These schools, on the other hand, were the theme of discussions before their establishments, during their service, and after their closures, and still have been the center of hot debates even today, which is not the main focus of this research now.

Tonguç and Hasan Âli Yücel (Minister of Education) and other staff within the context of the Village Institutes struggled with both the routine works of the schools inside and the objections to the schools outside. Tonguç, himself, particularly visited the schools for not only supervising, but also motivating and supporting school administrators, teachers, and students. Some of the visits were being accompanied by the President, The Minister and other bureaucrats. There were lots of criticisms and objections towards the Village Institutions from political to ideological. Partly as a consequence of these, the Minister, Hasan Âli Yücel resigned from the position for the policital reasons. By the way, Tonguç was appointed to as the member of Board of Education (Turkish:Talim ve Terbiye Kurulu) on the $21^{\text {st }}$ of September, 1946, and a new career, which would follow stressful and unhappy days, began for him. This change can be interpreted as the first official act towards the closure of the Village Institutes in that there lacked the support and leadership of Tonguç. The reason why Hasan Âli Yücel resigned or was forced to resign and Tonguç was appointed as a member of the Board of

\footnotetext{
${ }^{56}$ Gül Şimşek, and Cansın Mercanoğlu. "The Village Institutes' Experience of Turkey as a "Planning Case" Itself." Planlama, no. 28 (2018), p.275. doi: 0.14744/planlama.2018.32548.

57 Abdülaziz Kardaş, "Cumhuriyet Döneminde Bir Hareketin Son Temsilcisi: Ernis Köy Enstitüsü." Journal of International Social Research 10, $\quad$ no. $48 \quad$ (2017), p.187. doi:10.17719/jisr.2017.1492.

${ }^{58}$ Şimşek and Mercanoğlu. "The Village Institutes', p.270

${ }^{59}$ Ibid., p. 278
} 
Education hasn't been exactly revealed despite several evidence obtained from their own declarations and other literature. ${ }^{60}$

Upon these administrative changes, the wind of the Village Institutes were weakened. Until the transformation of the Village Institutions into the Teacher Training Schools in 1954, there were fierce debates and several regulations on the organizational structure of the schools. Further, the number of the students of the Village Institutes decreased. Finally, these schools were transformed into the teacher training schools through the legislations issued with the reference 6234 on the $27^{\text {th }}$ of January, 1954. The talks on this issue were recorded in the official reports of the debates by the member of the parliaments in the archieves of the Grand National Assembly of Turkey. ${ }^{61}$

\subsubsection{After the career in the Ministry of Education (1946-1960)}

Tonguç was appointed as one of the members of the Board of Education (Talim ve Terbiye Kurulu) on the $21^{\text {st }}$ of September, 1946 as displayed in Appendix 6. Having been appointed as the member of the Board of Education (Talim ve Terbiye), Tonguç focused on his new books such as The Elementary Education (İlkögretim Kavramı) in 1946 and Teacher Encyclopedia and Pedagogy Dictionary (Ö̈̆retmen Ansiklopedisi ve Pedagoji Sözlüğ̈̈) between 1949 and 1952 in different parts. Ha had written several books during his career, including Occupation and Vocational Education (İ̧ ve Meslek Eğitimi) in 1933. He also revised the new editions of his books such as The Village to be Developed (Canlandirtlacak Köy) in 1947.

Tonguç was appointed to the order of the Ministry of Education on the $11^{\text {th }}$ of September, 1950 without an exact reason in the official document on this order by the Minister of Education, Tevfik İleri. Upon this development, Tonguç applied for his retirement. There were several administrative investigations about his acts during his position between 1935-1946, which can be considered as revenge of his opponents. Almost after four years, Tonguç justified himself and was qualified with the retirement. He was officially declared as a retired officer on the $17^{\text {th }}$ of March, 1954, but the official retirement process was started from the $1^{\text {st }}$ of the October, 1953. This difference stemmed from the administrative investigations about him. When he justified all claims, he was assigned to be able to benefit from the rights of the retirement process. ${ }^{62}$.

His son, Engin Tonguç completed the Faculty of Medicine in Ankara University in 1951 and worked in Hamburg, Germany for seven years. Having returned to Turkey in 1958, he held different positions as a doctor during his career. He is noted for the building foundations of the occupational medicine, dealing with the maintenance of health in the workplace, in Turkey. He was the main person who revealed the archieves of Tonguç and helped memories to be known by the public. He was involved with several associations and took part in other organizations on the Village Institutes and Tonguç. He died on the $29^{\text {th }}$ of December, 2016 in Soma district of Manisa province in Turkey.

Upon the retirement, Tonguç was a civil person. Having travelled in several parts of the country, he decided to make a visit to Europe for both his son, Engin Tonguç's engagement and investigations on several education institutions like Pestalozzi Schools, which were based on

\footnotetext{
${ }^{60}$ Tonguç, Bir Eğitim Devrimcisi, p.515.

${ }^{61}$ T.B.M.M. Tutanak Dergisi. Ankara: T.B.M.M., 1954. Accessed May 20, 2020. https://www.tbmm.gov.tr/tutanaklar/TUTANAK/TBMM/d09/c027/tbmm09027034.pdf.

${ }^{62}$ Tonguç, Bir Eğitim Devrimcisi, p.655
} 
the experimental learning for child education, ${ }^{63}$ designed according to the phisolopy of Johann Heinrich Pestalozzi ${ }^{64}$ as well as the ones he had had education during the first years of his career in Karlshure. He made observations in schools adopting the philosophy of Pestalozzi in Germany and Switzerland. The first school was opened in Trogen, Switzerland. ${ }^{65}$

Having returned to Turkey, he published his book called as The Pestalozzi Children's Village (Pestalozzi Çocuklar Köyü) in 1960. Having been inspired the system in the Pestalozzi Children's Village and the philosophy of Pestalozzi, Tonguç emphasized the egalitarian society ideal. He not only follows the traces of Pestalozzi in his book, but also gives messages to his readers.

Tonguç's health problems intensified during the last parts of 1950s, and despite all treatment efforts of doctors, especially of his son, a doctor as well, he passed away on $24^{\text {th }}$ of June, 1960 in Ankara. Tonguç is buried in the Cebeci Asri Cemetery, located in the Cebeci quarter of central Ankara.

\section{2. İsmail Hakkı Tonguç as a successful educational leader (1919-1954)}

Examining the general leadership literature, one can see evidence of influence by effective leadership on countries and societies. ${ }^{66}$ Education arena is no exception. Educational leaders impact not just the organizations they serve but the communities in which they work, as well. ${ }^{67}$

Having framed the main flow in Tonguç's life, this subsection deals with his leadership styles based on the archieve content, particularly his letters and memories told by himself, his son, his students, his colleagues as well as his friends.

When we examine the abundant research on Tonguç and the Village Institutes, it is seen that Tonguç is often cited as an educational reformer, ${ }^{68}$ an educational theorist, ${ }^{69}$ and a teacher. ${ }^{70}$ Without doubt, there is no disagreement on such evidence from the literature. In this research, on the other hand, Tonguç is cited as "an educational leader" as the main focus of this inquiry is on his successful educational leadership attitudes and behaviors in terms of a historical perspective so that we can draw some conclusions by looking back and focusing the future. His career as the director of Elementary and Early Childhood Education encouraged us to address his leadership behaviours.

Much emphasis is given to the importance of educational leaders establishing and engaging, productive learning environments to enhance the quality of teaching and learning. In this sense,

\footnotetext{
63 S. Chester Parker, "Experimental Schools in Germany in the Eighteenth Century." The Elementary School Teacher 12, no. 5 (1912), 215-224. doi:10.1086/454113.

${ }^{64}$ Hermann Krusi. Pestalozzi: His Life, Work, and Influence. New York: Van Antwerp, Bragg \& Co., 1875.

${ }^{65}$ Arthur Bill. "The Pestalozzi Children's Village in Trogen, Switzerland." Psychiatric Services 25, no. 9 (1974), 599-601. doi:10.1176/ps.25.9.599.

${ }^{66}$ Kouzes, James M. Kouzes, and Posner Barry Z., The Leadership Challenge. Hoboken: John Wiley \& Sons, 2006.

${ }^{67}$ Patrick M. Jenlink, Educational Leadership and Moral Literacy: The Dispositional Aims of Moral Leaders. Lanham: R\&L Education, 2014.

${ }^{68}$ Türkoğlu, Tonguç ve Enstitüleri, p.15.

${ }^{69}$ Lütfi Kaleli, Anadolu'yu Aydınlatanlar. İstanbul: Berfin Yayınları, 2016, p.272.

70 Tonguç, Mektuplarla Köy Enstitüsü Yıllarl, p.5
} 
importance research-based evidence is required to encourage educational leaders to be much more influential. $^{71}$

Tonguç, called as "Tonguç Baba", together with many others, was a successful educational leader in Turkish History. ${ }^{72}$ His successful educational leadership can be modelled as shown in Figure 3.

Volume 12

Issue 4

August

2020

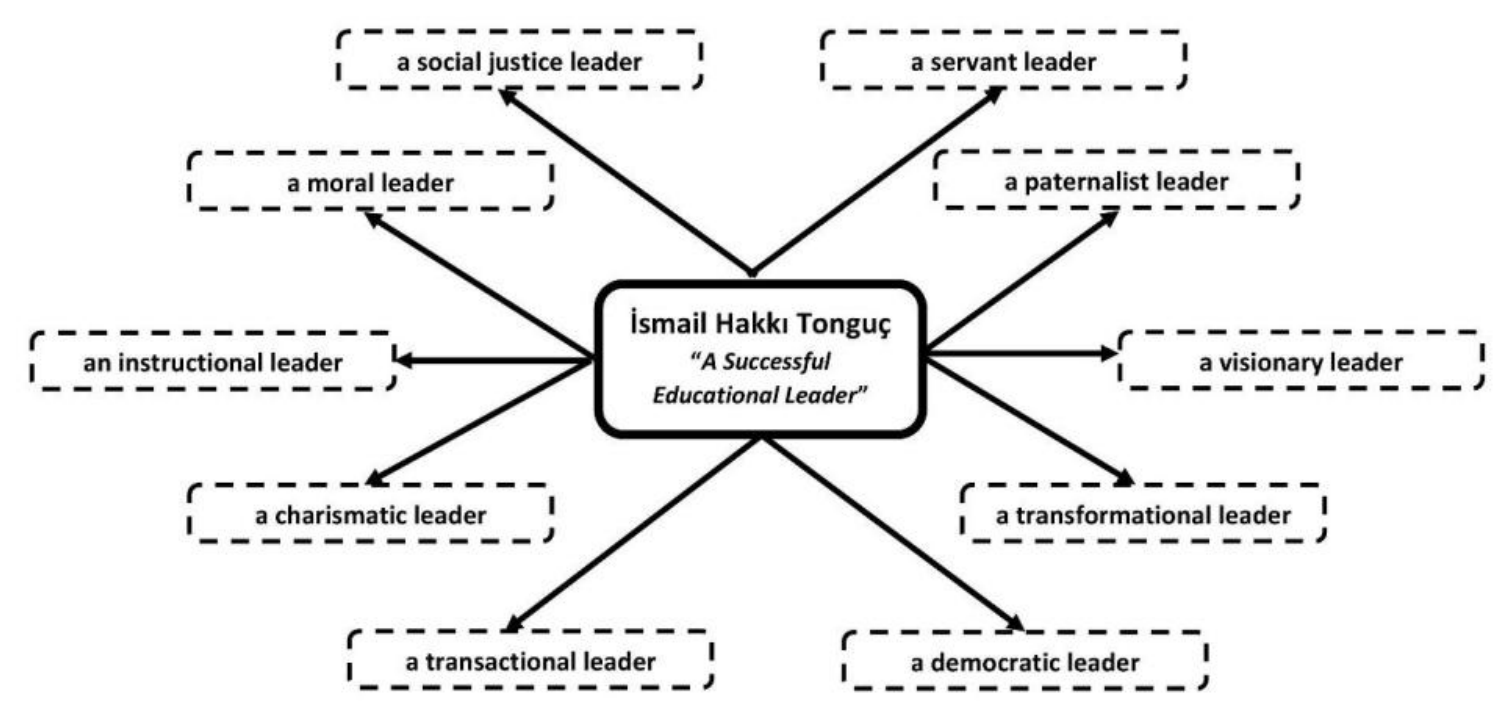

FIGURE 3. Tonguç "A Historical Successful Educational Leader”

In the literature on the educational leadership theory ${ }^{73}$ there is evidence to suggest that successful educational leaders embrace more than one leadership style based on the context. ${ }^{74}$ Considering the archieve content, and other data, it can be suggested that Tonguç adopted different educational leadership styles, as well.

Tonguç can be considered as a social justice/culturally responsive educational leader in that he voiced the equal educational opportunities for all children, particularly for those in the rural parts of the country. So much so that, in his book The Village to be Developed (Canlandirllacak Köy), he expressed his thoughts through his own sentences as follows ${ }^{75}$ :

\begin{abstract}
"...When we compare the knowledge which children in the big cities learn with that of those in the villages, one can see where the power has accumulated..."

"...When villagers come to cities for any reasons, they suffer much until they have adapted into the conditions in the cities. To be able to be a modern society means to remove the difference between cities and villages. This is not an easy task, but without some focus on this issue, the problems in the villages cannot be solved. Those developed countries are the ones that there are no huge gaps between cities and villages. Individuals in those countries are well-educated people..."
\end{abstract}

The international visits of Tonguç and the books he read from important figures may have had an effect on shaping his egalitarian philosophy and passion for social justice.

\footnotetext{
71 Partrick Duignan, Educational Leadership: Together Creating Ethical Learning Environments. Cambridge: Cambridge University Press, 2012, p.3.

${ }^{72}$ Kaleli, Ibid., p.8

73 Tony Bush, and Glover Derek. "School leadership models: what do we know?" School Leadership \& Management 34, no. 5 (2014), p. 554. doi:10.1080/13632434.2014.928680.

${ }^{74}$ Angus S. Mungal, and Richard D. Sorenson. Steps to Success: What Successful Principals Do Everyday. Lanham: Rowman \& Littlefield Publishers, 2020, p.38.

${ }^{75}$ Tonguç, Canlandırlacak Köy, p.78-79.
} 
Tonguç can be considered as a servant educational leader in that he served different positions in different parts of the county. Further, he perpetually visited the Village Institutes for inspection and supervision as well as spending time with teachers, students and villagers without being tired despite the limited access to the schools due to lack of transportation infrastructure at the time. The narrative below shows that the passionate of Tonguç was to serve his duty and contribute to his society. When we consider that eighteen of the twenty schools during his service were established in the villages, it must have been difficult task for him to access to these schools. Regarding this, his son Engin Tonguç told a story in an interview on the Village Institutes as follow: ${ }^{76}$

As it always happened many times, I was asked by my father to accompany him during a new school visit.

This time, we were going to Savaştepe Village Institute in Balıkesir. We arrived in Balıkesir by train from Ankara but it was late. Therefore, we missed the second train. The next train was one day later and there was no high way. My father didn't want to waste time and change the schedule. Then, my father talked to the chef officer in the train station, and learned that there was a freight train on the same route, but it was forbidden to take travellers on this train as it was dangerous. My father insisted and introduced the importance of this visit. The chef officer asked my father to sign a document assigning the responsibility to my father. When we arrived in our destination, we were almost black due to the coal dust.

Tonguç can be considered as a moral/ethical educational leader in that he always welcomed the assignments of him. Further, when Hasan Âli Yücel became the Minister of Education, he sincerely voiced that he could submit his resignation in case the new minister would want to recruit his own team. ${ }^{77}$ Moreover, he paid utmost care of the financial issues and focused his efforts on mininum expenditure but maximum benefit. Moreover, Tonguç gave importance the ideas of other scholars in education, such as Kerschensteiner or Dewey, and benefitted from all different perspectives. He was a modest person with full of affection of his duty. ${ }^{78}$ Regarding this, it can be noted that Tonguç had attended several visits to abroad for a variety of purposes with the support of his country. Still, he could have settled in one of the countries he visited, particularly one in Europe, but he would never think of this. He always may have dreamed of returning to his country to serve effectively. Moral and ethical leaders think others rather than themselves.

Tonguç can be considered as a paternalist educational leader in that he used to give importance to all students as if they had been his children. Further, there is evidence in a variety of sources that İsmail Hakkı Tonguç's nickname was “Tonguç Baba". Baba means father in Turkish Language. Most people call him Tonguç Baba because he always cared the students and the staff. Another evidence comes from a letter that sent to all school administrators in the Village Institutes on the $13^{\text {th }}$ of December, $1943 .^{79}$

\footnotetext{
...I have visited the ten village institutes for the last six months, visiting in person. I have also asked for the opinions of others who visited these schools before. Despite good practices in the schools, there are some issues which we need to address immediately. For example, some of the administrators used violence on students, so we would have to take very strict measures to prevent this. Some teachers threaten the children with low marks, so the students don't like these teachers. The school administrators must focus on this issue. Moreover, the main philosophy of ours is that the students should decide and practice all the tasks they can by themselves under the supervision of their teachers. In some of the tasks, the students sometimes can't find enough food and other necessities. This is a very disappointing issue which needs utmost care...
}

\footnotetext{
${ }^{76}$ İstanbul Araştırmaları Enstitüsü. "Engin Tonguç Köy Enstitülerini anlatıyor." YouTube. May 25, 2017. https://www.youtube.com/watch?v=wmB4s1nt3S8

${ }^{77}$ Tonguç, Bir Eğitim Devrimcisi, p.248

${ }^{78}$ Türkoğlu, Tonguç ve Enstitüleri, p.561.

79 Tonguç, Mektuplarla Köy Enstitüsü Yılları, p.65.
} 
Tonguç can be considered as a visionary educational leader in that he always sought for innovations in terms of better education and service. Further, his books and other writings always navigated students from disadvantaged contexts. He also shed light on the officials through his thoughts in his books. During his directorate, he prepared reports to draw routes for the future of the country. Along with the translations of important books by Tonguç, his books such as The Village to be Developed (Canlandirtlacak Köy), Pestalozzi Children's Village (Çocuklar Köyü), Occupational and Vocational Education (İş ve Meslek Eğitimi), The Elementary Education (İlkögretim Kavramı) as well as many others can be considered as a guide even today.

Tonguç can be considered as an instructional educational leader in that one of his main focus was teaching and learning in the Village Institutes. There is evidence to suggest that he wrote books and prepared outlines on teaching activities. He would supervise teachings of teachers in person, by visiting the schools. He always read a vast array of books on education, sociology and other areas on child education. ${ }^{80}$

Tonguç can be considered as a transformational educational leader in that the Village Institutes are the main samples and evidence of this. Before the opening the Village Institutes, he would articulate the necessity and the urgency of the transformation. He finally made his seniors build the new schools as a reform in education. He particularly drew attention to the onthe-job training.

Tonguç can be considered as a transactional educational leader in that he never ignored violence on the students. He was strictly objected to improper behaviours among students and staff and always articulated that he would punish the responsible people in the event of improper behaviours. On the other hand, he always appreciated his colleagues and students whenever he had the chance to talk to them. One can understand this from the fact that there are lots of photos with children who sincerely smiled and were happy despite their disadvantaged conditions.

Tonguç can be considered as a democratic educational leader in that the main premise of the Village Institutes, and so his educational philosophy was that participative/shared leadership. He always lead teachers and administrators to involve students in decision-making process. ${ }^{81}$

Tonguç can be considered as a charismatic educational leader in that he had a deep influence on the staff and the students during his visits in the Village Institutes. One can see the traces of his charismatic influence on the staff and the students in his letters. Thanks to his rhetoric and metaphoric language, he could influence others through even his letters. There is below an excerpt from one of his letter written for addressing one of the school administrators Nejat İdil on the $23^{\text {rd }}$ of the May, $1942 .{ }^{82}$

\footnotetext{
"My brother Nejat,

.......We have to use our intelligence effectively to maintain our services. We can never say that this is the end of our power in the event of a problem, nor do we give up. The nation waits the most sincere and the greatest contribution of us during these hard times. You should educate the students in your school so well that they would do their best even if they didn't take their salaries when they start to teach following the graduation. You must work like ants for the winter. You must organize your work in line with the objectives of the school. It is very difficult to lead people and to persuade
}

\footnotetext{
${ }^{80}$ Tonguç, Bir Ĕ̆itim Devrimcisi, p.56-57.

${ }^{81}$ Türkoğlu, Tonguç ve Enstitüleri, p.329.

${ }^{82}$ Tonguç, Mektuplarla Köy Enstitüsü Yılları, p.58.
} 
them. Sometimes you can be open, sometimes you can explain later, or sometimes you may need to threaten them so that you can achieve the goals...

\section{Discussion}

This study has sought to examine the successful educational leadership by Tonguç, the director of Elementary and Early Childhood Education between 1935-1946 and one of the founders of the Village Institutes. The primary data for this research were obtained by gleaning the official archieve content, his letters, his books, and previous research.

İsmail Hakk1 Tonguç was a significant figure who would be discovered one day in the future $^{83}$. Tonguç was a great educational leader. ${ }^{84}$ It is seen that there were calls on his exemplary leadership almost fifty years ago. In an interview with Ramazan Gökalp Arkın, one of the students of Tonguç, he stated that Tonguç was among the most valuable teachers of theirs. ${ }^{85}$

As stated in the writings of Tonguç, he advocates the democratic organizational structure. School administrators, teachers and students could collaborate, and students were able to have words on almost all issues in the Vilage Institutes. Students could also criticize and state their opinions. ${ }^{86}$ When we examine the previous research, it is seen that İsmail Hakk1 Tonguç was a successful educational leader whose colleagues, friends, and students loved him. Further, he was a historical successful educational leader whom lots of people respect him and focus on his thoughts and ideas as well as the Village Institutes.

Today, educators and scholars in educational arena conduct scientific studies and cite a variety of different educational reformers. However, one of the main premise of this study is that there were/have been important figures in our education history. Those important figures should be addressed scientifically and new staff must be encouraged to read books and articles on these people. İsmail Hakkı Tonguç is among them, as well. Novice teachers and administrators can learn much from the educational background of Tonguç and his works.

\section{Conclusion}

By concluding the research, it must be noted that framing Tonguç's biography, we intended to build a background for his leadership attitudes and behaviours even though we didn't provide a detailed historical content. Still, this can be argued to provide a framework to understand a successful educational leader from the historical perspective. On the other hand, the objections to the Village Institutions, Tonguç, himself as well as his educational thoughts occuring in the history can be considered as the interest of a historical research. However, we didn't address these issues in detail as the main premise of this study was to highlight his historical successful educational leadership.

There may be historical figures in other countries across the world. However, given Turkey, a country in which diverse nations settled during the course of history, there have been a great number of historical significant figures from policy to education. At this precise point, nations can and must draw conclusions from the good practices and the important figures in their

\footnotetext{
${ }^{83}$ Süleyman Edip Balkır, Eğitimimizde ve Köycülüğümüzde İki Anıt Hasan Ali Yücel [ve] Hakkı Tonguç. İstanbul: Ar1, 1969, p.92.

84 Nedime Köşgeroğlu, Beli Kırılan Devrim: Köy Enstitüleri ve Kadın Kalemler. Ankara: Alter Yayınlar1, 2010, p.51.

85 Arslan Kaynardağ, Eğitim ve Yayın: Ramazan G. Arkın’la Söyleşi. İstanbul: Arkın Kitabevi, 1985, p.43.

${ }^{86}$ Yalçın, “Bir Eğitimcinin Anıları”, p.128.
} 
history without getting stuck in biased expressions. In a historical issue, the archieves provide evidence, much or less, for two parts of any controversial issue. We well know that the controversial issues can/should be addressed. However, when it comes to draw conclusions from the good practices, everyone must focus on the morals and good practices to be able to move on the future.

Through this research, we argue that there were a great number of historical figures in terms of education in Turkish History. In collaborating with past and present, we can revise and develop our educational philosophies and can look at the future with realistic predictions.

\section{Implications}

The historical-biographical analysis of Tonguç can yield important results for today. In terms of the theoretical implications, this research points to the fact that growing, selection and developing educational leaders from the lowest position to the highest one in the hierarchy of the bureaucracy of the Ministry of Education must be a priority of an education system. Unfortunately, this is not available for Turkish Education System today. However, it would be wrong to assert that there is no system of growing, selection and developing educational leaders. The evidence for this argument comes from the 2023 Vision Document, published by Ministry of Education in 2018. One of the main targets of the 2023 Vision Document is to manage and to develop human resources. There is an emphasis on the making school leadership as a career resting on expertise and accountability. Moreover, another important theoretical implication in this study is that characteristics are very important for educational leaders, so a holistic approach should be embraced while selecting and appointing educational leaders rather than other subjective criterias.

As for practical implications, there is evidence to suggest that there were close and sincere relationships among the school administrators, teachers, students, and Ministry of Education at the time despite personal differences. Especially, being able to send letters to stakeholders was an effective means of communication at the time. Today, when we consider technological developments, there are more opportunities to pursue this. Further, Tonguç and Hasan Âli Yücel and many other educational leaders were those who had proved their abilities, skills and competences before being appointed to their careers. This must be a priority today, as well. In other words, when we consider the better opportunities for personal development and great support of the state for those who want to develop their competencies, the merits of educational leadership can be enhanced easily.

\section{Limitations and Further Research}

This research is subjected to some limitations, as well. Generally, the limitations in historical studies lay simply within the availability of materials. Regarding this, there has been a good system of the archieve content that can be accessed from online in the Directorate General of State Archives. Even though there have been abundant research on İsmail Hakk1 Tonguç, it would be useful if there were more evidence from those who had studied in the Village Institutes as teachers or students as well as the villagers themselves, or their descendants. Then, there may be more detailed accounts of historical analysis. Another limitation is that some of the archieve content comes from the Ottoman Archieves of Republic of Turkey. For the future research, scholars from different disciplines can conduct research in collaboration to be able to better understand the period before Republic of Turkey in terms of educational leaders. 


\section{Highlights}

Based on evidence cited in this research, these highlights can be noted for today and future of educational leadership in Turkey:

1. Educational leaders should provide themselves with better knowledge and skills before the service.

2. Educational leaders should have a good command of a foreign language, particularly English, in the hierarchy of the bureaucracy of the Ministry of Education so that they can follow the latest developments across the world.

3. Educational leaders must have the chance to examine the history of education, particularly previous educational leaders to grasp good and bad practices.

4. Educational leaders should have strong characteristics during their leadership journeys so that they can stand still.

5. Educational leaders must be encouraged to know the local context in which they lead in terms of both human resources and school conditions to be able to determine their leadership strategies.

6. All educational leaders in the hierarchy of the bureaucracy of the Ministry of Education should be able to visit and observe in different contexts across the world so that they can make comparisons between similarities and differences.

\section{Bibliography}

ALTIN, Fevzi Özgür. Köy Enstitülerinin Kapatılmasında Yazllı Basının Rolü: Gündem Berlileme Kuramı Kapsaminda Ulus ve Vatan Gazetelerinin Incelenmesi. Master's thesis, At1lım Üniversitesi, 2020. Yöktez (616420).

BALKIR, Süleyman Edip. Eğitimimizde ve Köycülüğ̈̈müzde İki Anıt Hasan Ali Yücel [ve] Hakk Tonguç. İstanbul: Arı, 1969.

BCA:The decree of the selecting Tonguç for the $7^{\text {th }}$ celebration of the Napoli University, Directorate General of State Archives (236/594/10), Ankara, Turkey.

BCA:The official appointment of Tonguç as the Director of School Museum, Directorate General of State Archives (22/10/6), Ankara, Turkey.

BCA:The official appointment of Tonguç to the Board of Education, Directorate General of State Archives (186/35/2), Ankara, Turkey.

BCA:The official appointment of Tonguç, Directorate General of State Archives (136/3/20), Ankara, Turkey.

BCA:The official decree of his family's migration through Romania and settling in Eskişehir, Directorate General of State Archives (51/113/14), Ankara, Turkey.

BCA:The official document on Tonguç's visit to Russia, Germany and Bulgaria for several observations, Directorate General of State Archives (84/70/9), Ankara, Turkey.

BILL, Arthur. "The Pestalozzi Children's Village in Trogen, Switzerland." Psychiatric Services 25, no. 9 (1974), pp.599-601. doi:10.1176/ps.25.9.599. 
BOWEN, Glenn A. "Document Analysis as a Qualitative Research Method." Qualitative Research Journal 9, no. 2 (2009), pp.27-40. doi:10.3316/qrj0902027.

BUSH, Tony, and Derek Glover. "School leadership models: what do we know?" School Leadership \& Management 34, no. 5 (2014), pp. 553-571. doi: 10.1080/13632434.2014.928680.

BÜYÜKDÜVENCI, Sabri. The New Scholarship on Dewey. Edited by James W. Garrison. Berlin: Springer Science \& Business Media, 1995.

CEYLAN, Bahadırhan. "Köy Enstitülerinde Uygulanan Eğitim Programlarının Çoklu Zekâ Kuramı Açısından İncelenmesi”. Master's thesis, Sivas Cumhuriyet Üniversitesi, 2020. Yöktez (617223).

CİMİ, Mehmet. Tonguç Baba: Ülkeyi Kucaklayan Adam. İstanbul: Kanes Yayınları, 2015.

CRESWELL, John W. Qualitative Inquiry and Research Design: Choosing Among Five Approaches. Thousand Oaks: SAGE, 2013.

ÇELIK, Hacer. "Cumhuriyet Dönemi Sosyo-Kültürel Değişim Üzerinde Türk Aydınının Etkisi (İsmail Hakk1 Tonguç Örneği)." U.Ü. Fen-Edebiyat Fakültesi Sosyal Bilimler Dergisi, no.18 (2010), pp.111-124.

DENZIN, Norman K., and Yvonna S. Lincoln. The SAGE Handbook of Qualitative Research. Thousand Oaks: SAGE, 2017.

DUIGNAN, Patrick. Educational Leadership: Together Creating Ethical Learning Environments. Cambridge: Cambridge University Press, 2012.

GREENFIELD, William D. "Toward a Theory of School Administration: The Centrality of Leadership." Educational Administration Quarterly 31, no. 1 (1995), pp.61-85. doi:10.1177/0013161x95031001005.

GUERIN, Wilfred L., Earle G. Labor, Lee Morgan, Jeanne C. Reesman, and John R. Willingham. A Handbook of Critical Approaches to Literature. New York: Oxford University Press, USA, 1992.

HACALOĞLU, Yücel. Neden Köy Enstitüleri Değil?. İstanbul: Toprak Yayınları, 1962.

IZHAK Berkovich, "Reflections on Leadership Preparation Programs and Social Justice," Journal of Educational Administration 55, no. 3 (February 2017): pp. 261-279, https://doi.org/10.1108/jea-02-2016-0018.

İNALTEKİN, Abdullah. İsmail Hakkı Tonguç ve İsmail Hakkı Baltacıŏglu'nun Eğitim Görüşleri Ve Uygulamaları Üzerine Bir Çalışma. Master's thesis, Yeditepe Üniversitesi, 2002. Yöktez (117579).

İSTANBUL ARAŞTIRMALARI ENSTITÜSÜ. "Engin Tonguç Köy Enstitülerini anlat1yor." YouTube. May 25, 2017. https://www.youtube.com/watch?v=wmB4s1nt3S8. 
JENLINK, Patrick M. Educational Leadership and Moral Literacy: The Dispositional Aims of Moral Leaders. Lanham: R\&L Education, 2014.

KALELİ, Lütfi. Anadolu'yu Aydınlatanlar. İstanbul: Berfin Yayınları, 2016.

KANDİL, Mustafa. İsmail Hakkı Tonguç ve Mümtaz Turhan'ın Eğitim Görüşleri Üzerine Bir Değerlendirme. Master's thesis, Yeditepe Üniversitesi, 1986. Yöktez (357907).

KAPLAN, Ezgi. Cumhuriyet Dönemi'nde Kırsal Kalkınma Politikaları Örnek Bir Model: Köy Enstitüleri. Master's thesis, Mimar Sinan Güzel Sanatlar Üniversitesi, 2017. Yöktez (484237).

KARDAŞ, Abdülaziz. " Cumhuriyet Döneminde Bir Hareketin Son Temsilcisi: Ernis Köy Enstitüsü.." Journal of International Social Research 10, no. 48 (2017), pp.184-190. doi:10.17719/jisr.2017.1492.

KAYNARDAĞ, Arslan. Eğitim ve Yayın: Ramazan G. Arkın'la Söyleşi. İstanbul: Arkın Kitabevi, 1985.

KIRBY-BERKES, Fay. The Village Institute Movement Of Turkey: An Educational Mobilization For Social Change. PhD diss., Columbia University, 1960. ProQuest (0225862).

KORUR, Ahmet F. Democratic Education, The Village Institutes System in Turkey And its Art Education Component. PhD diss., The Ohio State University, 2002. ProQuest (3049056).

KOUZES, James M., and Barry Z. Posner. The Leadership Challenge. Hoboken: John Wiley \& Sons, 2006.

KÖROĞLU, Erkal. Türk Romanında Köy Enstitüleri Olgusu Üzerine Bir İnceleme. Master's thesis, Kastamonu Üniversitesi, 2019. Yöktez (593077).

KÖŞGEROĞLU, Nedime. Beli Kırılan Devrim: Köy Enstitüleri ve Kadın Kalemler. Ankara: Alter Yayınları, 2010.

KRIPPENDORFF, Klaus. Content Analysis: An Introduction to Its Methodology. Thousand Oaks: SAGE Publications, 2018.

KRUSI, Hermann. Pestalozzi: His Life, Work, and Influence. New York: Van Antwerp, Bragg \& Co., 1875.

MAKAL, Mahmut. Köy Enstitüleri ve Ötesi: Anılar, Belgeler. İstanbul: Literatür Yayınc1lı, 1979.

MCDOWELL, Bill. Historical Research: A Guide for Writers of Dissertations, Theses, Articles and Books. London: Routledge, 2013.

MUNGAL, Angus S., and Richard D. Sorenson. Steps to Success: What Successful Principals Do Everyday. Lanham: Rowman \& Littlefield Publishers, 2020.

PALESTINI, Robert H. A Commonsense Approach to Educational Leadership: Lessons from the Founders. Lanham: R\&L Education, 2012. 
PARKER, S. C. "Experimental Schools in Germany in the Eighteenth Century." The Elementary School Teacher 12, no. 5 (1912), pp. 215-224.

PATTON, Micheal Quinn. Qualitative Research \& Evaluation Methods: Integrating Theory and Practice. Thousand Oaks: SAGE Publications, 2015.

RECEP, Yalçın. "İsmail Hakkı Tonguç'un Türk eğitim sistemi üzerine görüşleri." Master's thesis, Yeditepe Üniversitesi, 2006. Yöktez (188777).

STUCKART, Daniel W., and Jeffrey Glanz. Revisiting Dewey: Best Practices for Educating the Whole Child Today. Lanham: R\&L Education, 2010.

ŞİMŞEK, Gül and Mercanoğlu, Cansın. "The Village Institutes' Experience of Turkey as a "Planning Case" Itself." Planlama, no. 28 (2018), pp. 261-281.

T.B.M.M. Tutanak Dergisi. Ankara: T.B.M.M., 1954. Accessed May 20, 2020. https://www.tbmm.gov.tr/tutanaklar/TUTANAK/TBMM/d09/c027/tbmm09027034.pdf.

TONGUÇ, Engin. Bir Eğitim Devrimcisi İsmail Hakkı Tonguç Yaşamı, Öğretisi, Eylemi. İzmir: Yeni Kuşak Köy Enstitülüler Derneği Yayınları, 2009.

TONGUÇ, Engin. Devrim Açısından Köy Enstitüleri ve Tonguç. İstanbul: Ant Yayınları, 1970.

TONGUÇ, Engin. Mektuplarla Köy Enstitüsü Yılları. Ankara: Güldikeni Yayınları, 1999.

TONGUÇ, İsmail Hakkı. Canlandırılacak Köy. İstanbul: Türkiye İş Bankası Kültür Yayınları, 2017.

TOSUN, Derya. "Köy Enstitülerinde Sanatsal Faaliyetler". Master's thesis, Dokuz Eylül Ünivertiesi, 2019. Yöktez (601876).

TURAN, Selahattin. "John Dewey's Report of 1924 and his recommendations on the Turkish educational system revisited." History of Education 29, no. 6 (2000), pp.543-555. doi:10.1080/00467600050163174.

TÜRKOĞLU, Pakize. Tonguç ve Enstitüleri. İstanbul: Yapı Kredi Yayınları, 1997

YALÇIN, Osman. Bir Eğitimcinin Anıları: İş Eğitimi Yolunda 46 Yıll. İstanbul, YA-BA Yayınları, 1983.

YIN, Robert K. Qualitative Research from Start to Finish, 2nd ed. New York: Guilford Publications, 2015.

ZABİTGIL, Özlem. "The Poetry of Turkish Village Institute-Educated Poets: Social Commentary on a Developıng Nation." PhD diss., The Pennsylvania State University, 2010. ProQuest (3436113). 


\section{APPENDIX 1}

The decree of the selecting Tonguç for the $7^{\text {th }}$ celebration of the Napoli University (Directorate General of State Archives [236/594/10])

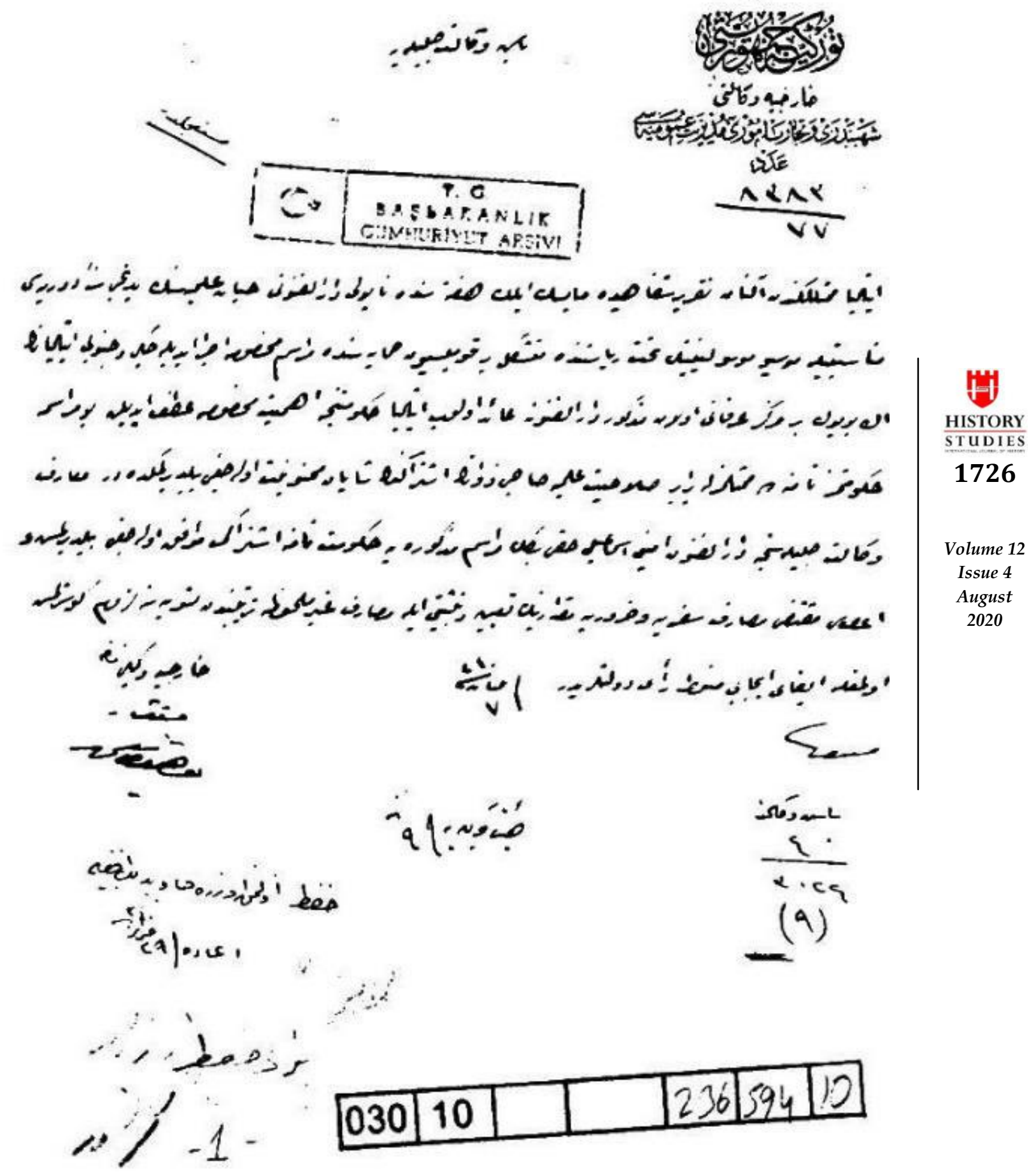




\section{APPENDIX 2}

The official appointment of Tonguç as the Director of School Museum (Directorate General of State Archives [22/10/6])

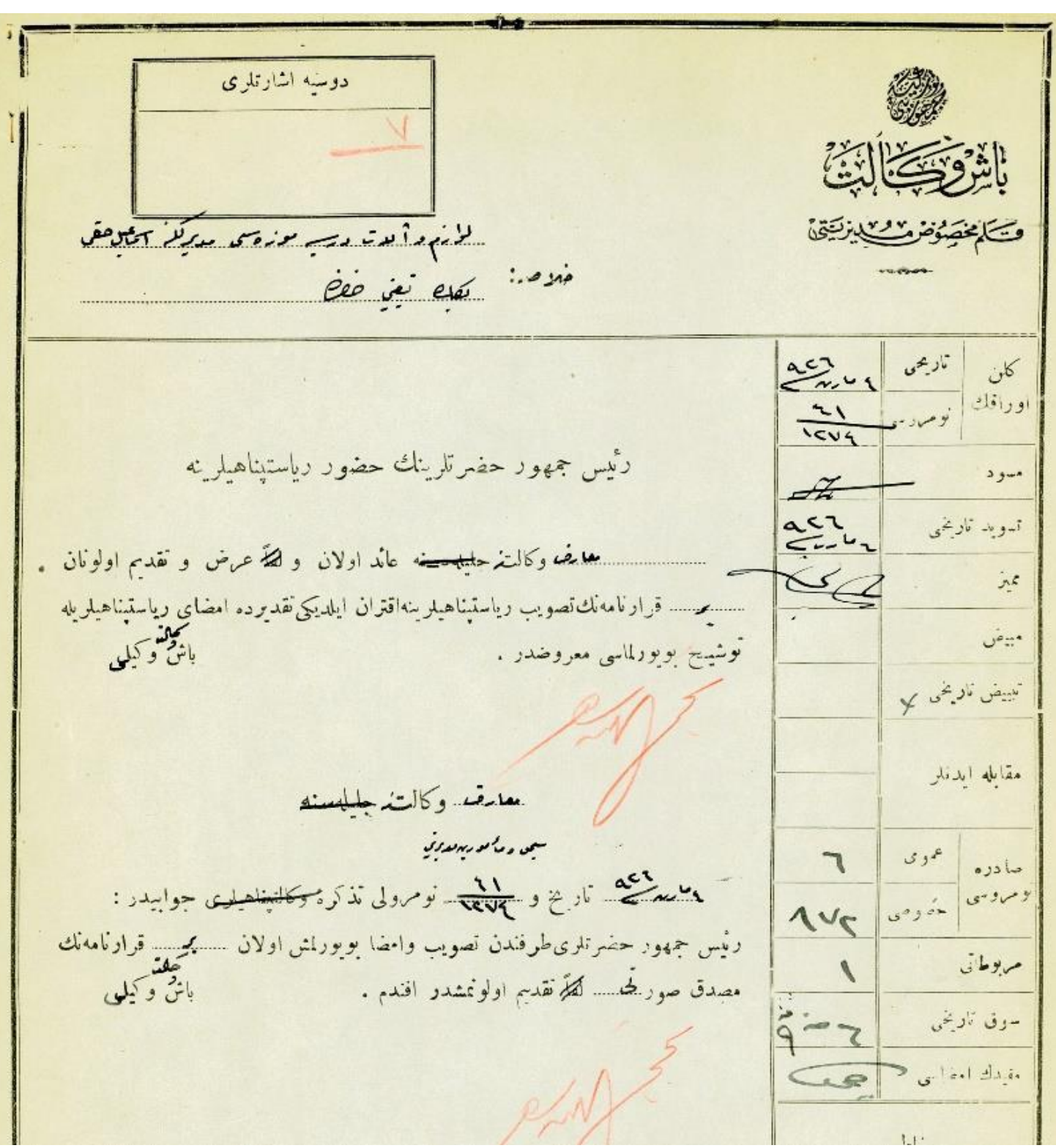




\section{APPENDIX 3}

The official decree of his family's migration through Romania and settling in Eskişehir (Directorate General of State Archives [51/113/14])

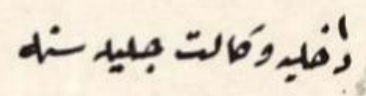

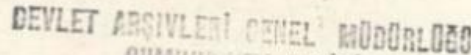 CUabiliain ARSiVi}

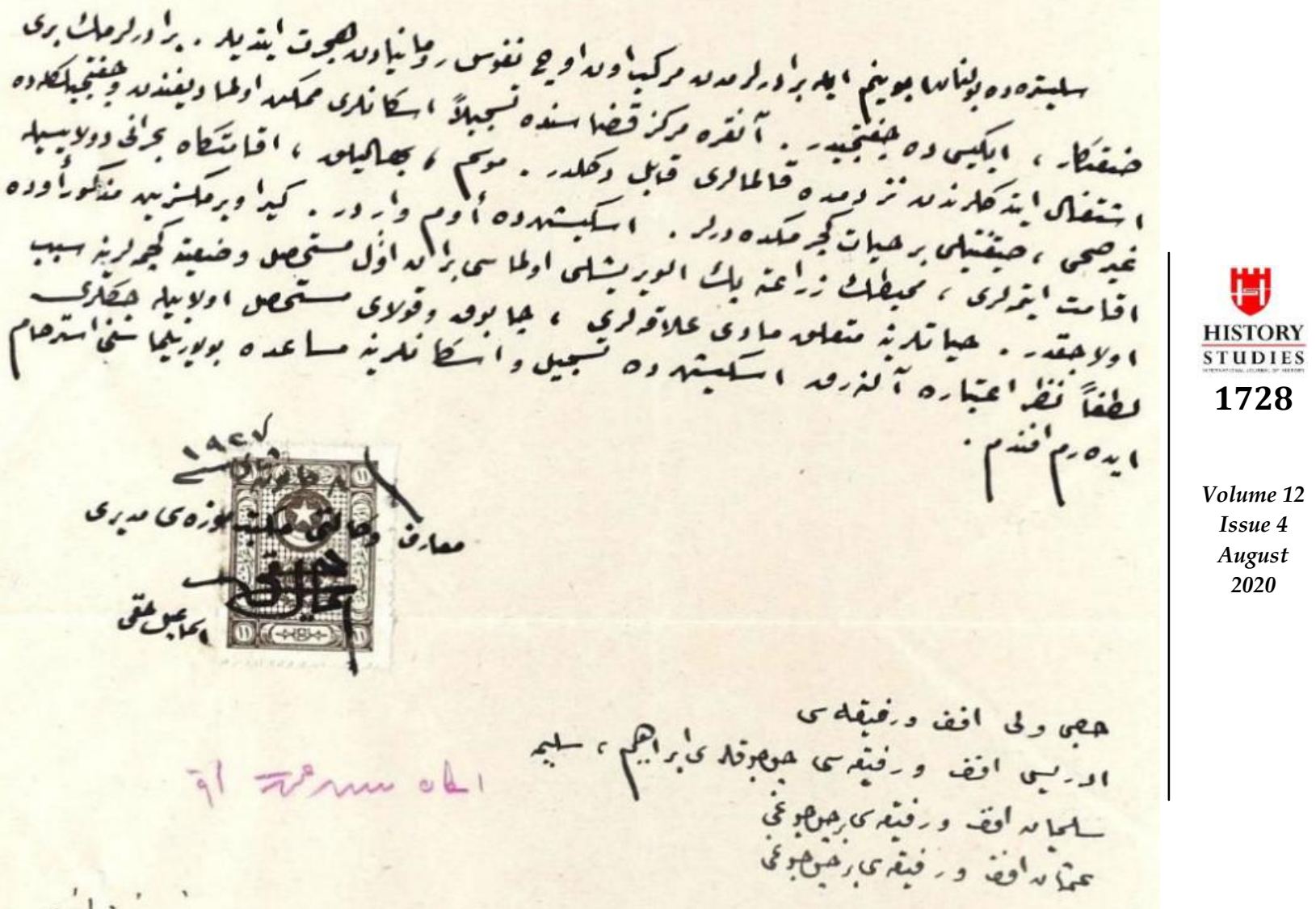




\section{APPENDIX 4}

The official appointment of Tonguç (Directorate General of State Archives [136/3/20])
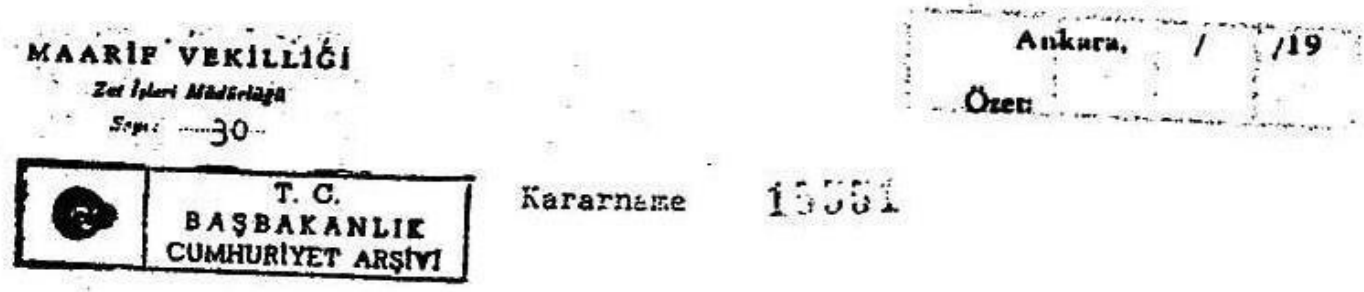

Kararneme 1 ioji.

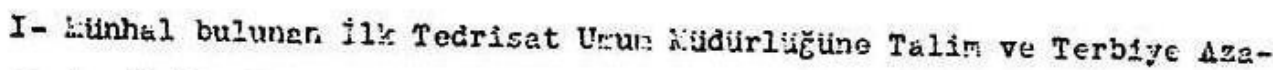

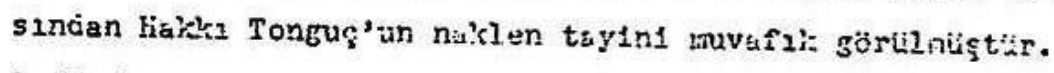

2- Eu icerarnemenin 1crasıne kaarif Vekill recuràr.
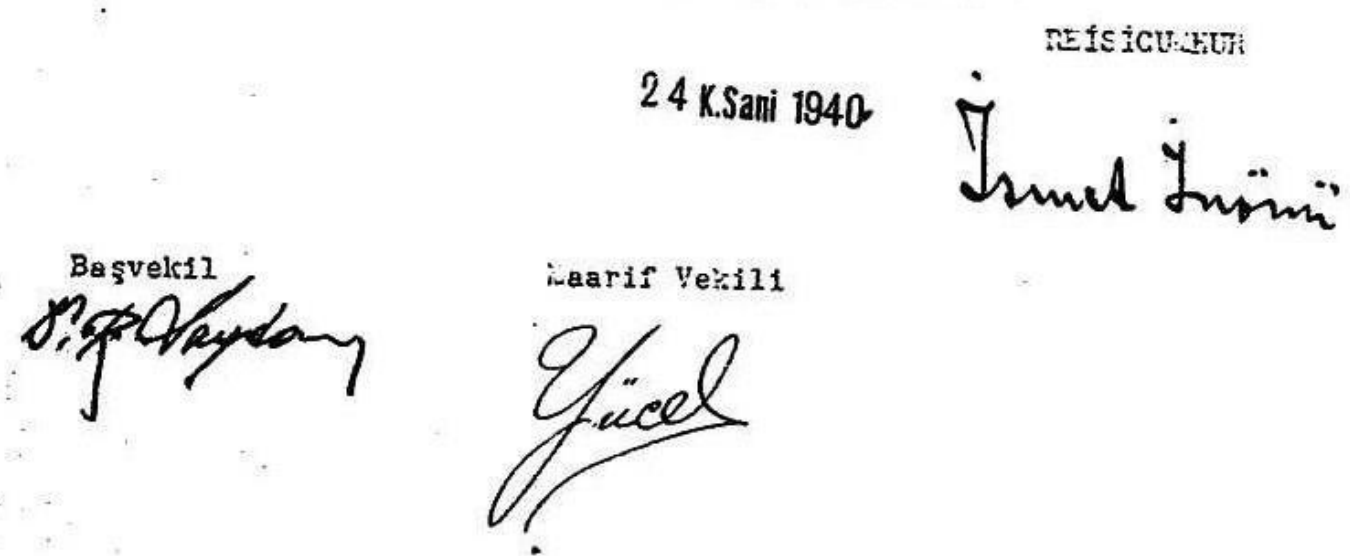
A Historical-Biographical Analysis of A Successful Educational Leader: İsmail Hakkı Tonguç

\section{APPENDIX 5}

The official document on Tonguç's visit to Russia, Germany and Bulgaria for several observations Directorate General of State Archives [84/70/9])

T. C.

BAŞVEKÅLET

KARARLAR MÖDORLÖGo

Karar sayısı

9350

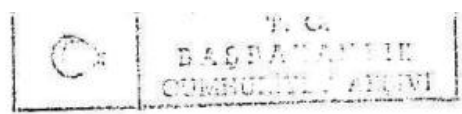

Kararname

Önümüzdeki ar̆ustos ayı içinde Hoskovada yapılacak ve köy kelkבnma işleri neticelerini gösterecek olan Ziraat sergisini, A Imanyada şehirli çocukların köylerde çalıştırılması ve entellektiuellerle köylii genci birlikte yaşatan ve galıştıran mecburî iş mükellefiyeti gibi teşkilâtları ve ahiren Bulgaristan`da kurulan köy çocušunu yetişdirme mehteplerini görmek ve bu yolda tetkikatta bulunmek üzere Ilktedrisat Umum Niudiuriu Ismail Hakkn Tonguç un Rusya,Almanya ve Bulgeristana gönderilmesi ve kendisine harcırahından başka Türkiye sınırlarından başlamak

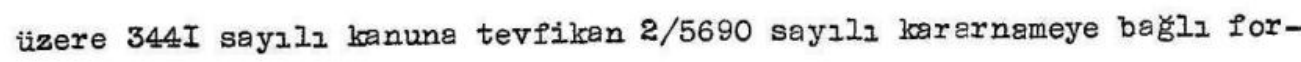
mülde yazll esaslar dairesinde günảelik ve siyasal pasaport verilmesi ve masraflarından Almanyaya isabet eden klsmanun kliring yolu ile ve Rusya ve Bulgaristana isabet eden kבsmlnבn da 938 takvim yבl döviz cet veller inin devlet talebe ve sutajiyerleri faslına Haarif Vekâleti namına konulan tahsisattan tediyesi; Maar if Vekillibinin 28/6/938 tar ih ve 2439 sayılı tezkeresi ve Maliye Vekilliginin 2I/7/938 tar ih ve 4025/I3248 sayll mutaleanemesi ïzerine Icra Vekilleri Heyet ince $23 / 7 / 938$ tarihinde onanmiştır.

$23 / 7 / 938$ REISICIMHHUR

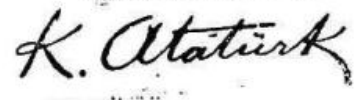

HISTORY STUDIES 1730

Volume 12

Issue 4

August

2020 
Ali Duran - Necati Cemaloğlu

\section{APPENDIX 6}

The official appointment of Tonguç to the Board of Education (Directorate General of State Archives [186/35/2])

T.'o.

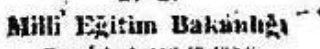

Zot listeti Müdürtǖós

Sox: $+30 / 1$

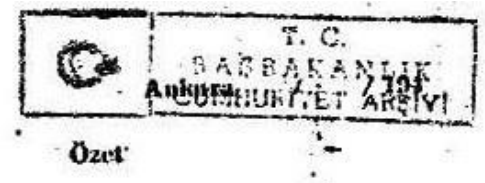

$K \perp R \& R$

20618

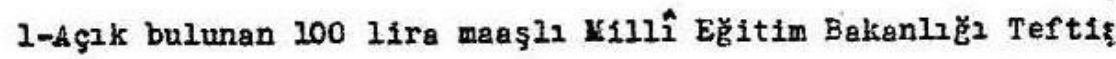
Kurulu Başkanlığına,Talim ve Terbiye Dairesi tyelerincien Yunus Kâzım Könı'nıln ve bu suretle açılan 100 11ra maş̧lı Talim ve Terbiye Daires1 tyeliğine de Ilk öğretim Genel vuaurú tsmail liakk Tonguç'un naklen tayinleri uygun göríl misş̧tür.

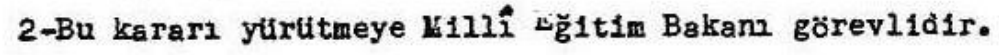

(itsini 1040

Issue 4

August

2020
COLHURBAŞKANT

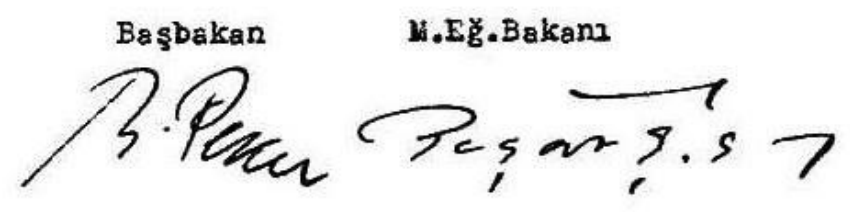

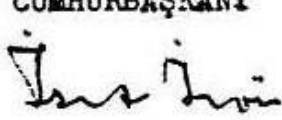

